\title{
Krzysztof Ożóg, The Role of Poland in the Intellectual Development of Europe in the Middle Ages [Krakow Historical Monographs, vol. I], Societas Vistulana, Kraków 2009, ss. 231.
}

Krzysztof Ożóg od lat zajmuje się badaniami nad historią szkolnictwa i kultury Polski późnego średniowiecza, zwłaszcza zaś dziejami Uniwersytetu Krakowskiego oraz jego wpływem na rozwój elit intelektualnych Królestwa Polskiego. Recenzowana książka ukazała się nakładem uznanego wydawnictwa Societas Vistulana, a inicjuje nową serię wydawniczą.

Praca składa się z dwóch części, z których każda liczy po cztery rozdziały. Część I, pt. „The Intellectual Development of Europe in the 12th-15th Centuries” ma za zadanie wprowadzić czytelnika w skomplikowaną materię przeobrażeń europejskiej kultury średniowiecza w niezmiernie ważnym dlań okresie od renesansu XII w. po początki renesansu, a więc w czasach powstania i rozwoju uniwersytetów, czy szerzej rzecz ujmując - rozwoju nauki i cywilizacji. Autor opisuje rozwój prawa kanonicznego, a zwłaszcza jego komentarzy dokonywanych przez bolońskich profesorów, na czele z Geoffrey de Thani, Henrykiem z Suzy, Aegidius de Fuscarariis. Jak słusznie zauważa, rozwój prawa kanonicznego był swoistą odpowiedzią środowisk kościelnych na renesans prawa rzymskiego, przy czym to właśnie kodyfikacja prawa kanonicznego, dokonana przez Gracjana w połowie XII w. była - jak to określa K. Ożóg - „first modern legal western system”. To dzięki utylitarnej działalności uczelni bolońskiej i paryskiej, uniwersytety cieszyły się poparciem papiestwa, wyrażanym w szeregu bulli papieskich. Miało to zarówno dobre, jak i złe strony, związane z ograniczeniami w zakresie programu nauczania, nakładanymi na poszczególne uczelnie. Papież Honoriusz III zakazał mianowicie nauczania w Paryżu prawa rzymskiego, natomiast ufundowana w 1245 r. uczelnia w Tuluzie przez niemal dwie dekady pozbawiona była prawa nauczania Arystotelesa na mocy bulli Innocentego IV, odwołanej przez Urbana IV w 1263 r. W tym miejscu książki znalazły się także rozważania Ożóga na temat recepcji dzieł Filozofa i jego arabskich komentatorów w środowiskach uniwersyteckich. Autor zauważa także stopniowy wzrost liczebności braci studenckiej, skutkujący potrzebą w połowie XIV w. zakładania nowych uniwersytetów.

Kolejny rozdział poświęcony został genezie i rozwojowi uniwersytetu w Oksfordzie. Autor podkreślił dużą rolę biskupa Lincolnu Roberta Grosseteste w fundacji uczelni. Przedstawił ponadto związki środowiska akademickiego Oksfordu z Uniwersytetem Paryskim. Rozdział trzeci („,The Development of the University Movement in Europe in the 13th Century - Formation of Minor Intellectual Milieus") ukazuje formowanie się sieci uczelni uniwersyteckich w Europie Zachodniej. Autor ukazuje różnorodność powodów, dla których różne środowiska przyczyniały się do tworzenia nowych uczelni. Czasami była to specjalizacja, jak w przypadku uczelni medycznej w Montpellier, czasami strajki i niepokoje skutkujące migracjami studentów do innych miast - wielki strajk w Paryżu

${ }^{1}$ K. Ożóg, The Role of Poland in the Intellectual Development of Europe in the Middle Ages, Kraków 2009, s. 15. 
w latach 1229-1231 przyczynił się do powstania uniwersytetów w Orleanie i Tuluzie. Czasami w grę wchodziły ambicje władców (Neapol, Salamanka, Valladolid) i papieży (uniwersytet papieski w Rzymie). Duże znaczenie dla przemian w intelektualnej geografii kontynentu miały także studia generalia tworzone przez mendykantów (K. Ożóg nie chce zauważyć na tym polu zasług zakonu cysterskiego). Niektóre studia generalia były afiliowane przy uniwersytetach - dominikańskie w Paryżu, Bolonii, Oksfordzie, Montpellier, Perugii, Padwie, franciszkańskie natomiast w Paryżu, Bolonii, Oksfordzie, Cambridge, Tuluzie. Inne w ośrodkach aspirujących do roli lokalnych centrów życia intelektualnego. W przypadku zakonu franciszkańskiego były to Asyż, Florencja i Kolonia. Dominikanie tworzyli swe szkoły wyższego rzędu po jednej w każdej prowincji zakonnej (było ich 27). Własny system studiów zorganizowali też augustianie-eremici i karmelici.

Ze środowiskami nauczycieli uniwersyteckich i studentów związany był rozwijający się dynamicznie rynek książki, tworzący w praktyce kulturę szkolną, o czym rozwodzi się Autor w trzeciej części tegoż rozdziału („A Manuscript Book as the Basic Tool for the Intellectual Work of University Millieus").

Pierwszą część pracy zamyka rozdział IV pt. „Intellectual Development of Central and East-Central Europe in the 14th-15th Centuries". K. Ożóg analizuje tu przemożny wpływ uczelni bolońskiej i paryskiej na rozwój życia intelektualnego „Młodszej Europy”, ale także na formowanie się pierwszych uniwersytetów w tej części kontynentu. Podkreśla tu również znaczny udział tutejszych władców (Karola IV, Kazimierza Wielkiego, Rudolfa IV Habsburga, Ludwika I Wielkiego), wspieranych przez miejscowe elity intelektualne, w procesach fundacyjnych uczelni. Trend wzrostowy rozwoju życia intelektualnego podtrzymywały kolejne fundacje uniwersyteckie w Erfurcie, Heidelbergu, Kolonii. Rozwojowi środkowoeuropejskich uczelni sprzyjał także ferment w Europie Zachodniej, związany z Wielką Schizmą i wojną stuletnią. Zwłaszcza kryzys uniwersytetu paryskiego wyniósł Pragę do roli najważniejszego centrum intelektualnego Europy Środkowo-Wschodniej. Z kolei ruch husycki zainicjowany poniekąd herezją Johna Wicleffa przyczynił się do wzrostu znaczenia Akademii Krakowskiej, w której do końca średniowiecza studiowało 20 tysięcy studentów, z czego tylko w XV w. trzy tysiące osób pochodziło z Węgier.

Pojawienie się w narracji uczelni krakowskiej jest zapowiedzią zmiany optyki w dalszej części książki, dotyczącej polskiego wkładu w rozwój kultury europejskiej. Część tę, zatytułowaną „Intellectual Achievements of Polish Intellectuals. Significant for Europe in the Middle Ages" otwiera rozdział poświęcony polskim intelektualistom w środowiskach uniwersyteckich Europy Zachodniej do pierwszej połowy XIV w. W opinii Autora o peregrynacjach Polaków do uniwersytetów można mówić od drugiej połowy XII w., natomiast łączną ich liczbę szacuje on na poziomie 300-400 osób do połowy XIV w. Na szczególną uwagę krakowskiego historyka zasłużyli Iwo Odrowąż, Witelon ze Śląska, Stefan Polak, Wawrzyniec z Polski, Marcin Polak, Mikołaj z Polski, Tomasz z Wrocławia². Do szczególnego znaczenia doszło środowisko polskich intelektualistów na uniwersytecie w Pradze, a także, choć w mniejszym jednak stopniu, także w Heidelbergu, o czym informuje Czytelnika rozdział II („Polish Intellectuals at the Universities of Prague and Heidelberg

2 Ibidem, s. 61-69. 
and Theit Influence of European Thought"). Z Polski na obu uczelniach kształciło się ok. tysiąca osób, przy czym nacja polska w Pradze, licząca w latach 1372-1418 ok. 30\% wszystkich immatrykulowanych, skupiała studentów ze Śląska, Turyngii, Pomorza, Łużyc, Miśni, Prus, Warmii, Litwy i Łotwy. Sporo miejsca poświęcono Mateuszowi z Krakowa i jego twórczości.

Zdaniem K. Ożóga, istnienie tak sporej liczebnie grupy intelektualistów w Polsce Kazimierza Wielkiego wpłynęło znacząco na uformowanie się w Krakowie uniwersytetu. Genezie fundacji ostatniego piastowskiego króla Polski oraz jego jagiellońskiemu odnowieniu poświęcony został rozdział III („Formation of the Krakow Intellectual Milieu”). Jak słusznie zauważa Autor, do śmierci Kazimierza Wielkiego powołano w Krakowie wydział Artium i prawdopodobnie medycyny, w tym czasie nie było natomiast w Polsce doktorów prawa ani teologów. Władysław Jagiełło podjął pierwsze działania w kwestii odnowienia uczelni w 1390 r. Wtedy to doszło do powołania wydziału prawa (1390-1393), w 1391 r. przybył natomiast Mateusz z Krakowa z misją uruchomienia wydziału teologicznego. W tym miejscu K. Ożóg zabiera swój głos w trwającej w historiografii od dłuższego czasu dyskusji nad odnowieniem bądź reformą jagiellońską Akademii Krakowskiej. Jego zdaniem Jagiełło pragnął powołać nowy uniwersytet w Krakowie z czteroma wydziałami, a nie odnowić dotychczas istniejący ${ }^{3}$. Do projektu przekonano też królową Jadwigę, a 11 stycznia 1397 papież Bonifacy IX zgodził się na utworzenie w Krakowie wydziału teologicznego, w związku z czym sprowadzono z Heidelbergu Mateusza z Krakowa. Dzięki kolejnym przywilejom papieskim: Jana XXIII (antypapieża), Marcina V, Bonifacego IX uczelnia krakowska cieszyła się dużą popularnością. Studiowali tu też cystersi, dominikanie, karmelici, franciszkanie, augustianie-eremici, benedyktyni i premonstratensi, a w 1450 r. dominikańskie studium generalne zostało inkorporowane do uniwersytetu. W dalszej części rozdziału Autor poddał analizie teksty używane w krakowskim środowisku uniwersyteckim do nauczania, w tym tworzone przez miejscowych profesorów, m.in.: Andrzeja Ważyka, Andrzeja z Kokorzyna, Sędziwoja z Czechła, Franciszka z Legnicy, Tomasza ze Strzępinia. Na utworzonym w 1400 r. wydziale prawa komentowano Decretum Gracjana, Decretales Grzegorza IX, Liber Sextus i Clementinae Bonifacego VIII. Recepcja prawa kanonicznego w Krakowie możliwa była dzięki Piotrowi Wyszowi, biskupowi krakowskiemu i kanclerzowi uniwersytetu wykształconemu w Padwie, a także Stanisławowi ze Skalbmierza, doktorowi dekretów, pierwszemu rektorowi. W dalszej części rozdziału zawarto analizę doktryn filozoficznych komentowanych w Krakowie ${ }^{4}$. Autor zauważa także, że w Krakowie odbyła się w 1431 r. komentowana szeroko teologiczna debata z Husytami - Prokopiuszem Wielkim i Piotrem Payne. Uczelnię reprezentowała grupa teologów z Mikołajem Kozłowskim, Andrzejem z Kokorzyna, Franciszkiem z Brzegu, Benedyktem Hesse, Janem z Paradyża, Eliaszem z Wąwolnicy i Janem Englotem, a przysłuchiwał jej się król z księciem Zygmuntem Korybutem i grupą świeckich panów.

W kończącym rozprawę rozdziale IV Czytelnik zostaje zapoznany z odziaływaniem krakowskiego środowiska intelektualnego na kulturę europejską. Jest rzeczą znamienną,

\footnotetext{
3 Ibidem, s. 87.

${ }^{4}$ Ibidem, s. 104 i nn.
} 
że od początku XV w. znawcy prawa wykształceni w Krakowie podjęli dyskusję nad fundamentalnymi kwestiami, na czele z prawem narodów do samostanowienia, funkcjonowaniem społeczeństwa, nad problemem wojny. Wyróżniały się w tym zakresie prace Stanisława ze Skalbmierza i Pawła Włodkowica. Uczeni krakowscy byli uczestnikami wielkich soborów reformacyjnych XV w., będąc przy tym zdecydowanymi zwolennikami koncyliaryzmu. Ważny był też wkład młodego uniwersytetu w kształtowaniu się i późniejszym rozwoju ruchu devotio moderna na ziemiach polskich. Nie zabrakło tu również osiągnięć uczelni jagiellońskiej w zakresie matematyki, astronomii i geografii.

Autor poszukiwał tu wreszcie przyczyn upadku międzynarodowego znaczenia Uniwersytetu Krakowskiego, jaki zaznaczył się w pierwszej połowie XVI w. K. Ożóg wiąże go z momentem powrócenia do nauczania filozofii arystotelejskiej na znaczną skalę, co datować można od 1536 r. Ograniczyło to znacznie napływ studentów z krajów europejskich, ale także liczbę studentów krakowskich w ogóle. W konsekwencji uniwersytet stał się w krótkim czasie uczelnią regionalną o coraz bardziej narodowym charakterze. Jak podkreśla Autor była to jednak tendencja ogólnoeuropejska ${ }^{5}$.

Książka Krzysztofa Ożóga oparta została na obszernym materialne źródłowym, przede wszystkim proweniencji krakowskiej na czele ze statutami uniwersyteckimi, metryką, kodeksem dyplomatycznym, księgami immatrykulacji i promocji. Autor wykorzystał także korpus prawa kanonicznego. Podobnie rzecz ma się z literaturą - bibliografia obejmuje liczne prace, w tym najnowsze opracowania dotyczące całego spektrum zagadnień poruszanych na kartach książki. Podkreślić należy także staranną szatę graficzną i równie znamienitą korektę, co jest bez wątpienia zasługą Wydawnictwa. Podczas lektury dostrzeżono jedynie niewielką liczbę lapsusów językowych czy potknięć redakcyjnych, jak np. na stronie 55 w przypisie 162. Nie mają one jednak wpływu na ogólnie wysoki poziom merytoryczny opracowania, wnoszącego cenny wkład w rozwój historiografii dotyczącej dziejów najstarszego polskiego uniwersytetu.

Krzysztof Ratajczak

Gdańskie Gimnazjum Akademickie, Wydawnictwo Uniwersytetu Gdańskiego, Gdańsk 2008: t. 1. Szkice z dziejów, pod red. E. Kotarskiego, s. 419; t. 2. Wybór źródet z XVI i XVII wieku, red. L. Mokrzeckiego, 323 s.; t. 3. Wybór źródel od XVI do XVIII wieku, red. Z. Nowak, 560 s.; t. 4. W progach Muz i Minerwy, red. Z. Glombiowska, 261 s.; t. 5 (Gdańsk 2011) Źródta i artykuly, red. L. Mokrzecki i M. Brodnicki, 225 s.

Powstałe w roku 1558 Gdańskie Gimnazjum Akademickie należało do najsłynniejszych szkół swoich czasów. Odegrało znaczącą rolę w kształtowaniu elit nie tylko Prus Królewskich, ale i sąsiednich terenów. Szkoła miała wybitnych profesorów i wykształciła

Tamże, s. 151-152. 